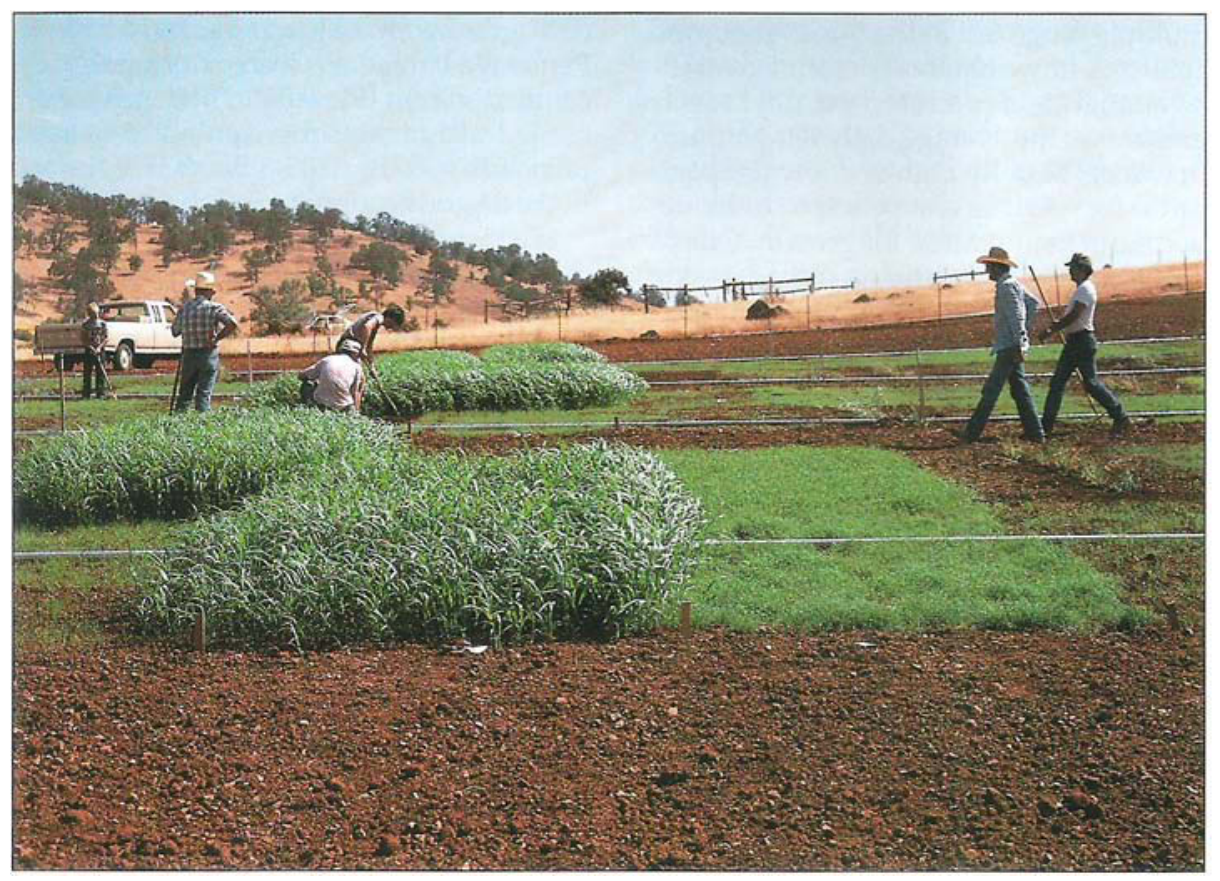

North American prairie grasses were most productive in a comparative study of irrigated warmand cool-season grasses. The high yield and later peak in production of warm-season grasses make them ideal for increasing the productivity of irrigated pastures in California. All grasses in the study survived reduced irrigation. Grazing cattle preferred dallisgrass over all other grasses.

\title{
Irrigated warm- and cool-season grasses compared in Northern California pastures
}

\author{
Melvin R.George $\quad \square \quad$ Peter B. Sands \\ - Charles B. Wilson \\ ๑ Roger Ingram \\ J J. Michael Connor
}

Being of tropical origin, warm-season grasses have a higher optimum temperature for growth than do cool-season grasses, and therefore remain productive during hot summers. Sudangrass (Sorghum sudanense), corn (Zea mays), bermudagrass (Cynodon dactylon), and dallisgrass (Paspalum dilatatum) are common warm-season grasses produced for forage in California. Cool-season grasses include such common irrigated pasture grasses as tall fescue (Festuca arundinacea), orchardgrass

(Dactylis glomerata), and perennial ryegrass (Lolium perenne).

\section{Seasonal studies}

Seasonal production potential, forage quality, grazing preferences, and production response to reduced irrigation are reported here for 17 warm-season grasses and 2 cool-season grasses. These studies were conducted over four growing seasons on a mixture of Auburn, Las Posas, and Argonaut loam soils at the University of California Sierra Foothill Research and Extension Center 17 miles northeast of Marysville.
Tillage and weed control were conducted from summer 1984 through spring 1985. On June 10, 1985, treble superphosphate $(0-40-0)$ was applied at the rate of 400 pounds per acre $(\mathrm{lb} / \mathrm{ac})$. Irrigation water delivery was delayed until late July, 1985. On July 25, 1985, 14 entries were seeded (table 1). On August 13 of that year, sprigs of the limpograss and two bermudagrass entries were transplanted. On May 20, 1986, Verde kleingrass and laurisagrass were added to the experiment. The experimental design was a randomized complete block with 6-foot by 10foot plots. The 19 entries were replicated six times.

All plots were fertilized April 1 and June 20,1986 , with $150 \mathrm{lb} / \mathrm{ac}$ of ammonium nitrate (35-0-0). In 1987, ammonium phosphate sulfate (16-20-0) was applied at $375 \mathrm{lb} / \mathrm{ac}$ on May 20 and August 20. In 1988, the same fertilizer was applied at 625 $\mathrm{lb} / \mathrm{ac}$ on May 15. In 1989, $230 \mathrm{lb} / \mathrm{ac}$ were applied June 15.

In 1986 and 1987, all replications were irrigated weekly, beginning April 20 and April 13, respectively. The amount of wa- ter that evaporated from a nearby Class A evaporation pan during the previous week was applied during weekly irrigations. In 1988 and 1989, weekly, biweekly, and monthly irrigation treatments were applied to two replications each (see sidebar). Irrigation treatments applied an amount of water equal to the previous week's pan evaporation. Irrigation treatments were begun in 1988 on May 20 and in 1989 on May 2. In 1988, all replications received weekly irrigations from April 12 through May 20.

On May 20,1986, the plots were mowed to control weeds. Yield measurements began on June 10, 1986. A 3-foot by 10-foot area was mowed from the center of each plot. A 4-inch-high stubble remained following monthly harvests.

In 1986, harvested forage was subsampled and analyzed for crude protein, acid detergent fiber (ADF), and in-vitro dry matter digestibility (IVDMD). Acid detergent fiber is a measure of the cellulose and lignin concentration of forage. As ADF increases, total digestible nutrients (TDN) usually decrease. In-vitro dry mat- 
ter digestibility is a laboratory method of estimating digestibility. It is a measure of the amount of dry matter digested by rumen microbes in 48 hours.

To estimate relative preference for each entry, grazing time in each plot was determined on the morning after the June, July, August, and September harvests in 1987 and 1988 (see sidebar). Three heifers were allowed to graze the remaining forage in each 6- by 10 -foot plot following the harvest of a 3-by 10-foot strip. The heifers were fasted overnight and allowed to graze for 2 hours. During that period an observer assigned to each heifer recorded the amount of time spent actively grazing (grazing and chewing) in each plot. Grazing time began with the first bite and continued until the animal left the plot or ceased active grazing.

Forage dry weight, crude protein, ADF, IVDMD, and grazing time were subjected to analysis of variance, and treatment means were separated using Duncan's multiple range test at the $5 \%$ level of probability. A growth index (percentage of total annual yield produced per day) was regressed on the average daily temperature (mean of the daily high and low temperatures) for each harvest period to estimate optimum temperature for growth. Quadratic equations describing the regression of the growth index on average daily temperature were determined for warm-season and cool-season species.

\section{Forage yield}

Grasses native to the North American prairie (Osage Indiangrass, Aldous little bluestem, Kaw big bluestem, Kanlow switchgrass) and Lehmann's lovegrass were the most productive entries over the 4 -year period of the trial (table 1) and were not significantly different $(P<0.05)$.

Orchardgrass yield for the 4 years was significantly lower $(P<0.05)$ than that of all other entries. The bermudagrasses, limpograss, tall fescue, laurisagrass, common dallisgrass, Verde kleingrass, and Pensacola bahiagrass were not significantly different $(P<0.05)$. Their yields exceeded that of orchardgrass, but were significantly less $(P<0.05)$ than that of the highest-producing entries.

The warm-season grass yields exceeded the yields of the cool-season species in most months from May through September (fig. 1). May 1987 and June 1988 were exceptions, but cool-season yields were not significantly higher on those dates. In each year of the study, the warm-season grasses reached their peak yields after the cool-season grasses. The cool-season species had peak yields in April, May, or June; the warm-season species produced their highest yields in June, July, or August. The warm-season grasses were dormant during winter; the cool-season grasses remained green all year. Although late fall through early spring production by the cool-season species was low, there was sufficient forage to harvest

TABLE 1. Annual forage dry matter yield for 4 years; ADF, crude protein, and IVDMD for 1986 ; and grazing time for 1987 and 1988 for 17 warm-season and 2 cool-season grasses at the Sierra Foothill Research and Extension Center ${ }^{*}$

\begin{tabular}{|c|c|c|c|c|c|c|c|c|c|c|c|}
\hline \multirow[b]{2}{*}{$\begin{array}{l}\text { Scientific } \\
\text { name }\end{array}$} & \multirow[b]{2}{*}{$\begin{array}{c}\text { Common } \\
\text { name }\end{array}$} & \multirow[b]{2}{*}{ Cultivar } & \multicolumn{5}{|c|}{ Dry matter yield (Ib/ac) } & \multirow[b]{2}{*}{ ADF } & \multirow[b]{2}{*}{$\begin{array}{l}\text { Crude } \\
\text { protein }\end{array}$} & \multirow[b]{2}{*}{ IVDMD } & \multirow[b]{2}{*}{$\begin{array}{c}\text { Grazing } \\
\text { time }\end{array}$} \\
\hline & & & 1986 & 1987 & 1988 & 1989 & $\begin{array}{l}\text { 4-year } \\
\text { mean }\end{array}$ & & & & \\
\hline & & & . & ......... & $\ldots l b / a c .$. & - & 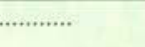 & ................. & $\ldots \% \ldots$ & (n......... & $\min$ \\
\hline \multicolumn{12}{|c|}{$\begin{array}{l}\text { Warm-season grasses } \\
\text { Andropogon }\end{array}$} \\
\hline $\begin{array}{c}\text { gerardi } \\
\text { Bouteloua }\end{array}$ & Big bluestem & Kaw & 7,204 cde & $7,632 a b$ & $7,582 \mathrm{~b}$ & $7,131 \mathrm{ab}$ & $7,387 \mathrm{abc}$ & 39.40 de & $7.38 \mathrm{bc}$ & $78.52 \mathrm{abcd}$ & $0.72 \mathrm{e}$ \\
\hline $\begin{array}{l}\text { curtipendula } \\
\text { Cynodon }\end{array}$ & Sideoats grama & El Reno & $8,583 a b c$ & 6,171 cdef & 6,537 cde & $6,056 \mathrm{~cd}$ & $6,837 \mathrm{bc}$ & $40.75 \mathrm{~cd}$ & $5.25 \mathrm{c}$ & $69.60 \mathrm{~g}$ & $0.25 \mathrm{e}$ \\
\hline $\begin{array}{l}\text { dactylon } \\
\text { Cynodon }\end{array}$ & Bermudagrass & $\mathrm{CC} 1$ & 6,627 def & 5,586 efgh & $4,544 \mathrm{hi}$ & 4,877 ef & $5,409 f$ & 38.32 ef & $7.44 \mathrm{bc}$ & 76.49 abcde & $4.64 \mathrm{bc}$ \\
\hline dactylon & Bermudagrass & Tifton 68 & 6,557 def & $4,596 \mathrm{hi}$ & $5,260 \mathrm{gh}$ & $3,972 \mathrm{gh}$ & $5,096 \mathrm{f}$ & $38.62 \mathrm{e}$ & $9.38 \mathrm{ab}$ & 76.89 abcde & $4.52 \mathrm{bc}$ \\
\hline $\begin{array}{l}\text { Cynodon } \\
\text { dactylon } \\
\text { Eragrostis }\end{array}$ & Bermudagrass & Pasto Rico & 5,522 ef & $4,724 \mathrm{hi}$ & $5,170 \mathrm{gh}$ & $4,315 \mathrm{fgh}$ & $4,933 \mathrm{f}$ & $36.64 \mathrm{fgh}$ & $7.00 \mathrm{bc}$ & 72.82 defg & $6.78 \mathrm{bc}$ \\
\hline $\begin{array}{l}\text { curvula } \\
\text { Eragrostis }\end{array}$ & $\begin{array}{l}\text { Boer lovegrass } \\
\text { Lehmann's }\end{array}$ & Catalina & $7,138 \mathrm{cde}$ & 6,873 abcde & 6,430 cde & 5,738 de & 6,545 cde & $41.59 \mathrm{bc}$ & $7.44 \mathrm{bc}$ & $59.92 \mathrm{~h}$ & $1.51 \mathrm{de}$ \\
\hline $\begin{array}{l}\text { lehmanniana } \\
\text { Eragrostis }\end{array}$ & lovegrass & Lehmann's & $7,823 \mathrm{bcd}$ & $7,456 \mathrm{abc}$ & $6,961 \mathrm{bcd}$ & $6,388 \mathrm{bcd}$ & $157 \mathrm{abc}$ & $44.28 \mathrm{a}$ & $6.38 \mathrm{bc}$ & $9.36 \mathrm{~g}$ & $0.44 \mathrm{e}$ \\
\hline $\begin{array}{l}\text { trichoides } \\
\text { Hemarthria }\end{array}$ & Sand lovegrass & Bend & $8,703 a b c$ & 6,341 cdef & 5,872 efg & 5,061 ef & 6,494 cde & $36.92 \mathrm{fg}$ & $6.56 \mathrm{bc}$ & $70.74 \mathrm{fg}$ & $0.18 \mathrm{e}$ \\
\hline $\begin{array}{l}\text { altissima } \\
\text { Panicum }\end{array}$ & Limpograss & Bigalta & $5,438 f$ & $4,708 \mathrm{hi}$ & 5,921 efg & 5,703 de & 5,442 & $\mathrm{f} 36.96 \mathrm{fg}$ & $7.69 \mathrm{bc}$ & $82.01 \mathrm{a}$ & $4.05 \mathrm{~cd}$ \\
\hline $\begin{array}{l}\text { coloratum } \\
\text { Panicum }\end{array}$ & Kleingrass & Selection 75 & $7,930 \mathrm{bcd}$ & 6,520 bcdef & 6,255 def & $6,119 \mathrm{~cd}$ & 6,706 bcd & $35.03 \mathrm{~h}$ & $7.25 \mathrm{bc}$ & 74.46 cdefg & $0.97 \mathrm{e}$ \\
\hline $\begin{array}{l}\text { coloratum } \\
\text { Panicum }\end{array}$ & Kleingrass & Verde & - & 5,882 defgh & $5,484 \mathrm{fg}$ & 5,670 de & 5,679 ef & 一 & - & - & $1.45 \mathrm{de}$ \\
\hline $\begin{array}{l}\text { virgatum } \\
\text { Paspalum }\end{array}$ & Switchgrass & Kanlow & $9,643 \mathrm{a}$ & 6,450 bcdef & $7,154 \mathrm{bc}$ & 5,586 de & $7,208 \mathrm{abc}$ & $35.99 \mathrm{gh}$ & $8.81 \mathrm{ab}$ & $69.40 \mathrm{~g}$ & 0.70 \\
\hline $\begin{array}{l}\text { dilatatum } \\
\text { Paspalum }\end{array}$ & Dallisgrass & Common & $7,592 \mathrm{bcd}$ & 4,890 ghi & $4,634 \mathrm{hi}$ & $3,641 \mathrm{~h}$ & $5,189 \mathrm{f}$ & $43.53 a$ & $7.38 \mathrm{bc}$ & 76.14 bcdef & $14.07 \mathrm{a}$ \\
\hline $\begin{array}{c}\text { notatum } \\
\text { Pennisetum }\end{array}$ & Bahiagrass & Pensacola & 6,108 def & 6,023 defg & 5,855 efg & 4,957 ef & 5,736 def & $39.45 \mathrm{de}$ & $8.94 \mathrm{ab}$ & $68.89 \mathrm{~g}$ & $0.43 \mathrm{e}$ \\
\hline $\begin{array}{c}\text { orientale } \\
\text { Schizachyrium }\end{array}$ & Laurisagrass & & - & 5,459 fghi & $5,502 \mathrm{fg}$ & 4,501 efg & $5,166 \mathrm{f}$ & - & - & - & $0.62 \mathrm{e}$ \\
\hline $\begin{array}{c}\text { scoparium } \\
\text { Sorghastrum }\end{array}$ & Little bluestem & Aldous & $7,630 \mathrm{bcd}$ & $7,025 \mathrm{abcd}$ & $8,460 \mathrm{a}$ & 7,331 a & $7,612 a b$ & $41.60 \mathrm{bc}$ & $8.44 a b c$ & $71.18 \mathrm{ab}$ & $1.31 \mathrm{de}$ \\
\hline nutans & Indiangrass & Osage & $9,299 a b$ & 7,849 a & $8,516 a$ & $6,863 a b c$ & $8,132 \mathrm{a}$ & $43.10 \mathrm{ab}$ & $7.06 \mathrm{bc}$ & $77.40 \mathrm{abcd}$ & $0.38 \mathrm{e}$ \\
\hline $\begin{array}{l}\text { Cool-season g } \\
\text { Dactylis }\end{array}$ & asses & & & & & & & & & & \\
\hline $\begin{array}{l}\text { glomerata } \\
\text { Festuca }\end{array}$ & Orchardgrass & Akaroa & $3,457 \mathrm{~g}$ & $3,720 \mathrm{j}$ & $4,295 i$ & $2,596 \mathrm{~h}$ & $3,517 \mathrm{~g}$ & $36.56 \mathrm{gh}$ & $11.31 \mathrm{a}$ & $81.18 a b$ & $7.29 b$ \\
\hline arundinacea & Tall fescue & Fawn & $3,762 \mathrm{~g}$ & 5,616 efgh & $5,335 \mathrm{gh}$ & 5,690 de & $5,101 \mathrm{f}$ & $34.45 \mathrm{~h}$ & $11.75 \mathrm{a}$ & $79.69 a b c$ & $5.69 \mathrm{bc}$ \\
\hline
\end{tabular}


in April before the onset of growth by the warm-season species.

Forage yield on June 14, 1989, was low because the period between the May 17 harvest and this date was unusually cool. The average daily maximum temperature for the period from May 9 to June 11 was $79^{\circ} \mathrm{F}, 6^{\circ}$ below normal. Twelve days during the period had maximum temperatures that were more than $10^{\circ}$ below normal.

The optimum average daily temperatures for growth of the cool-season and warm-season entries were $70^{\circ}$ and $79^{\circ} \mathrm{F}$, respectively. Cool-season grasses such as orchardgrass and tall fescue are most productive when temperatures are cooler. Cool-season grasses remain green all year but produce poorly in high summer temperatures. Warm-season grasses such as switchgrass, bluestems, bermudagrass, crabgrass, johnsongrass, and corn begin to grow in late spring, and do most of their growing during the warmest months of the year.

\section{Forage quality}

One criticism of warm-season grasses has been their apparently low forage quality.
Many studies show that their crude protein levels rarely exceed $16 \%$, and may be as low as 3\%; most reports range from 6 to $10 \%$ crude protein. In this study, the coolseason grasses were highest in crude protein, but not significantly higher than little bluestem, Pensacola bahiagrass, switchgrass, and Tifton 68 bermudagrass (table 1).

Lehmann's lovegrass and dallisgrass were highest in ADF, but not significantly different from Indiangrass. Tall fescue was lowest in ADF. Limpograss had the highest IVDMD, but not significantly higher than big bluestem, Indiangrass, orchardgrass, and tall fescue. Boer lovegrass had the lowest IVDMD.

\section{Forage management}

Studies of the five highest-producing entries in other states show that forage quality remains high if high leaf-to-stem ratios can be maintained. Rotational grazing and short stubble heights encourage leaf production that will result in high-quality grazing. Rotational grazing with rest periods of 4 weeks or more is considered essential if cattle reduce stubble to less than 6 inches and consume nearly all leaves. If the stubble height is maintained at 10 to 16

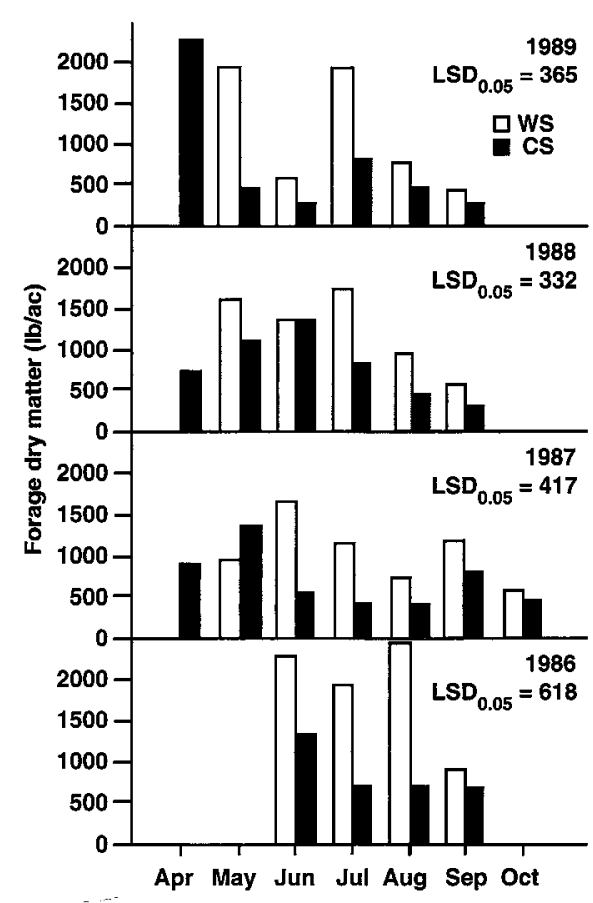

Fig. 1. Monthly forage dry matter yields of warm-season (white bar) and cool-season (dark bar) grasses, 1986-1989.

\section{Grasses survive reduced irrigation}

Total yield during 1988 and 1989 was significantly higher $(\mathrm{P}<0.05)$ for the weekly irrigation treatment than for the biweekly and monthly treatments (table 2). Yield of the biweekly irrigation treatment was significantly greater $(P<0.05)$ than the monthly treatment.

In 1988, monthly yield estimates for the weekly and biweekly irrigation treatments were not significantly different $(\mathrm{P}<0.05)$ (fig. 2). The yield of the monthly irrigation treatment was significantly reduced $(\mathrm{P}<0.05)$ from the more frequent irrigation treatments, except for the May harvest, which was 2 days before initiation of irrigation treatments. In 1989, there was no difference in the May yields, which were harvested 2 weeks after initiation of irrigation treatments. There were only slight differences in yields between treatments on

\begin{tabular}{|c|c|c|}
\hline $\begin{array}{l}\text { Irrigation } \\
\text { treatments }\end{array}$ & 1988 & 1989 \\
\hline \multicolumn{3}{|c|}{ 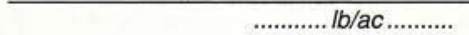 } \\
\hline Weekly & $6,635 a$ & $6,885 \mathrm{a}$ \\
\hline Biweekly & $5,075 \mathrm{~b}$ & $5,330 \mathrm{~b}$ \\
\hline Monthly & $3,930 \mathrm{c}$ & $4,155 \mathrm{c}$ \\
\hline
\end{tabular}

"Yields in the same column followed by the same letter are not significantly different $(P<0.05)$.
June 14. In July and August, yields for each treatment were significantly different $(\mathrm{P}<0.05)$. In September, monthly and weekly treatments were significantly different $(\mathrm{P}<0.05)$, but they did not differ from the biweekly treatment.

In 1988, scattered rain through June probably reduced evapotranspiration and helped to maintain enough soil moisture to allow the weekly and biweekly irrigation treatments to produce similar yields; the monthly irrigation treatment gave insufficient supplementation of natural rainfall and soil moisture to maintain forage yield. In 1989, May and June were cooler than normal and characterized by daily traces of precipitation that reduced evaporation and suppressed forage production. Warmer temperatures starting in mid-June increased evapotranspiration and subsequent soil moisture depletion sufficiently to reduce forage production in the bimonthly and monthly irrigation treatments during July and August.

Poor spring rainfall, late spring irrigation water availability, and water rationing during drought combine to make soil moisture availability for irrigated pasture undependable in northern California. While most of the warm-season grasses in this study were more productive than the cool-season grasses, they did not demon- strate any special advantage over the coolseason species under reduced irrigation. Similar forage yields May 17, 1989, following the first year of irrigation treatments suggest that the yield capacity of plots subjected to reduced irrigation was not permanently damaged.
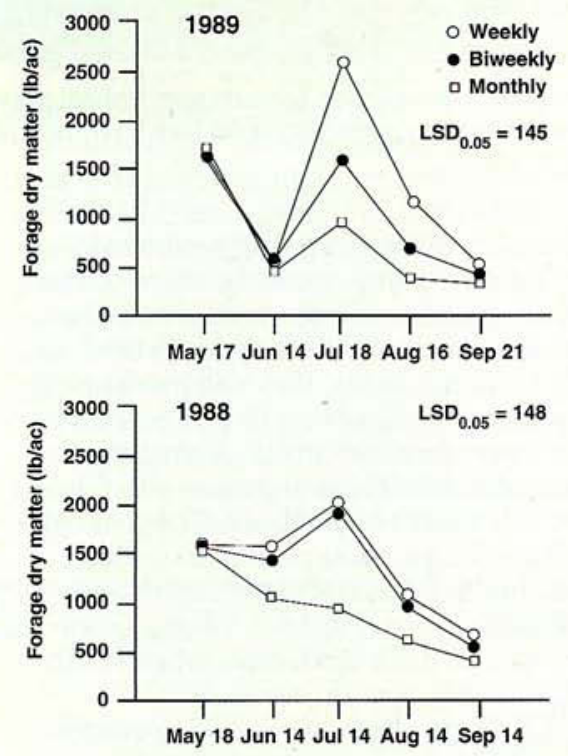

Fig. 2. Forage dry matter for weekly, biweekly, and monthly irrigation treatments for each harvest date in 1988 and 1989. 

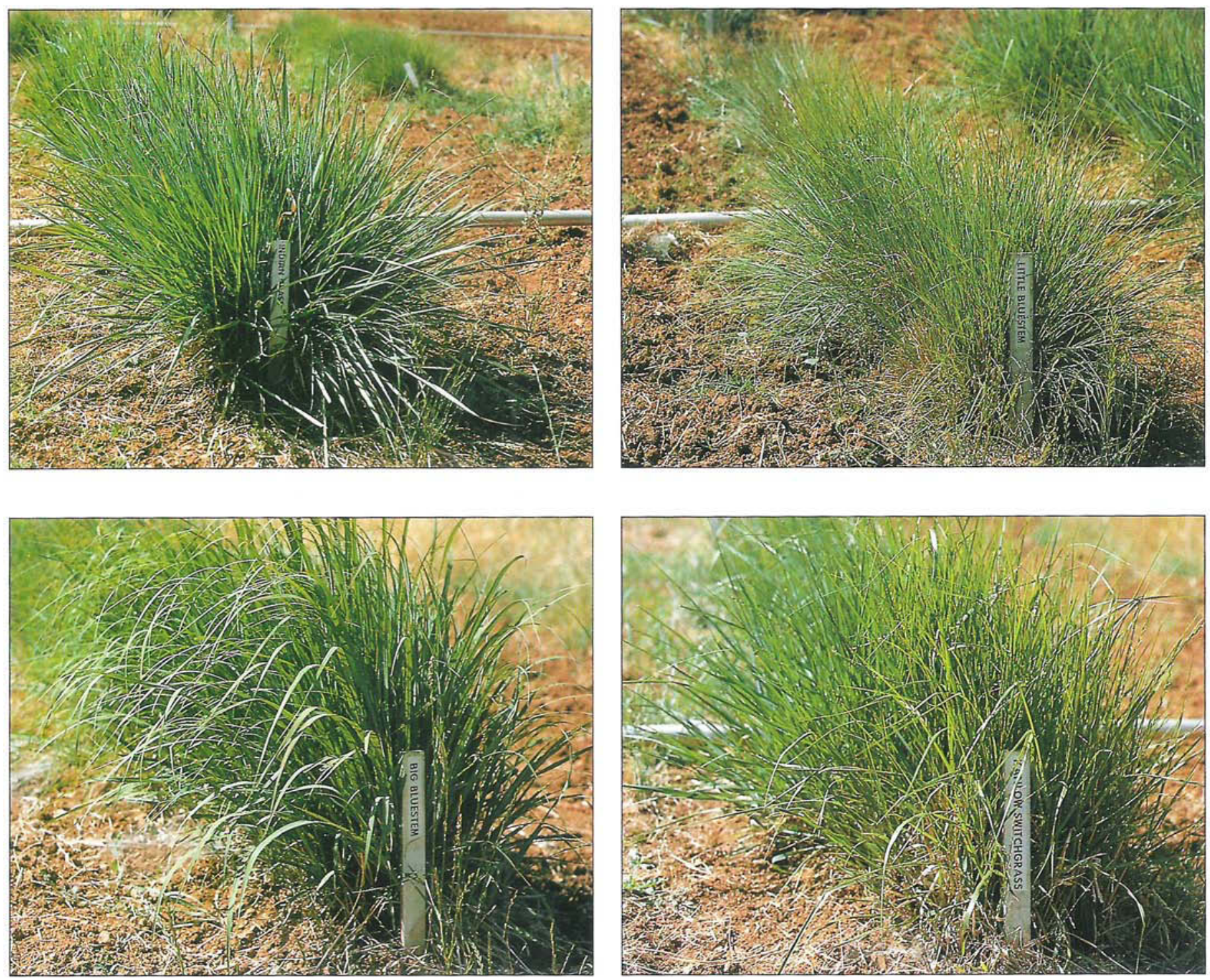

The four warm-season grasses with highest four-year average forage dry matter yields were (top left) Indiangrass, (top right) little bluestem, (above left) big bluestem, and (above right) switchgrass.

inches, continuous grazing is allowed.

Tall fescue and orchardgrass are commonly found in Northern California irrigated pastures. While they performed poorly in this study, they will produce winter and early spring forage, especially if they are fertilized in fall. A mixture of cool- and warm-season grasses should provide the benefits of each. The cool-season species are most productive when moisture is abundant and temperatures are cool in spring and fall. Warm-season grasses are most productive when warmsummer temperatures prevail.

Of the five highest-producing entries, Lehmann's lovegrass was lowest in IVDMD, but not significantly lower than switchgrass and little bluestem. Lehmann's lovegrass was highest in ADF. Lehmann's lovegrass also tended to spread via seed into areas where it was not wanted, so we do not recommend its use.

\section{Conclusion}

Warm-season grasses have the potential to increase irrigated pasture yields later in summer than the cool-season grasses that have been traditionally used. Warm-season grasses were more productive than cool-season grasses and they remained productive later in the summer. By extending peak pasture productivity and increasing total yield, warm-season grasses have the potential to increase irrigated pasture production, carrying capacity, and productivity per acre. Increasing productivity without increasing fertilizer or irrigation inputs will increase fertilizer and water use efficiency. Reduced irrigation during water rationing should not have long-lasting affects on the forage yield of warm- or cool-season species.

Warm-season grasses usually are lower in quality than cool-season grasses. To maintain higher forage quality and to gain the early production benefits of cool-season species, a mixture of warm-season grasses and cool-season grasses and legumes would be preferable. This condition exists in many valley and foothill pastures where dallisgrass, a warm-season species, is present.

Continued research should be conducted on forage quality, animal performance, livestock-forage systems, and competitive relationships among warm-season grasses, cool-season grasses, and legumes. There is no reason, however, why interested producers should not test Indiangrass, switchgrass, big bluestem, and little 


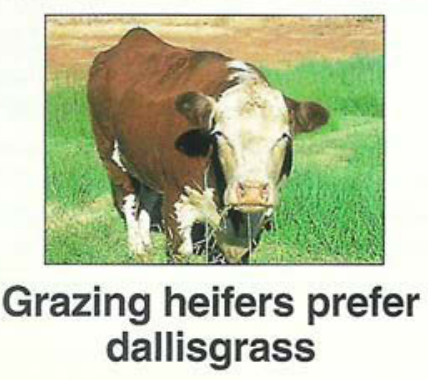

Grazing heifers spent more time grazing dallisgrass than any other entry (table 1). Each heifer averaged more than 14 minutes grazing dallisgrass during each of eight 2-hour grazing periods during two growing seasons. Orchardgrass, tall fescue, and the three bermudagrass entries were grazed an average of 4.5 to 7.3 minutes during each of eight grazing periods.

The five highest-producing entries received little use. Grazing livestock often prefer forage with which they are familiar, and dallisgrass, orchardgrass, and tall fescue are the dominant grasses in irrigated pastures at the Field Station. Bermudagrass is present in some pastures.

bluestem on a small scale to determine their utility in individual operations. The lead author can provide a list of midwestern seed sources.

Management practices can be developed based on research in other states. Irrigation scheduling and fertilizer practices would be similar to those for existing coolseason pastures. Rotational grazing of warm-season grasses is crucial to managing warm-season forage quality. In a rotational grazing system, a postgrazing stubble height of about 6 inches should increase pasture leafiness. Under continuous grazing, stubble heights of 10 to 16 inches should be the target. Because these species are extremely robust and competitive, they may gradually exclude existing coolseason species if seeded into an existing pasture.

M. R. George is Cooperative Extension Range and Pasture Specialist and P. B. Sands is Cooperative Extension Staff Research Associate, Department of Agronomy and Range Science, UC Davis; C. B. Wilson is Farm Advisor, Sutter-Yuba counties; $R$. Ingram is Farm Advisor, Nevada County; and J. M. Connor is Superintendent, Sierra Foothill Research and Extension Center.

The authors wish to acknowledge the California Cattlemen's Association for financial support of this project and the USDA Soil Conservation Service Plant Materials Center for providing seed.

Fight weeds and increase forage:

\section{Using oats as a companion crop in establishing alfalfa}

\begin{abstract}
W. Thomas Lanini Jack P. Orr

During alfalfa stand establishment, an oat companion crop helps fight weeds and can increase first-cutting forage yield, experiments indicate. No long-term negative impacts on alfalfa production were observed.
\end{abstract}

Weed control during stand establishment is a critical issue in alfalfa hay production. Weeds can strongly reduce nutritional quality in the first cutting, and by lowering alfalfa density they may reduce yields of subsequent cuttings. Weed seed produced during establishment goes into the soil seed bank, and alfalfa fields with low stand densities are more susceptible to later weed invasions.

Weed control in seedling alfalfa is often unattainable with available herbicides. An oat companion crop can be an alternative to using herbicides; at the same time, it adds to the forage yield during the first year's production. In the Midwest, alfalfa is often established in spring, using an oat companion crop seeded at 50 to 100 pounds per acre (lb/ac). Most areas utilizing oat companion crops are not irrigated as irrigated companion crops are considered more competitive. Although this practice has been used widely elsewhere, it has not been used in California because of concerns that competition from the oats might reduce alfalfa vigor and stand density.

Experiments were conducted at three locations in California to evaluate the use of an oat companion crop under several sets of growing conditions. The objectives were to assess (1) forage yield, (2) first cutting forage composition and (3) alfalfa and weed densities as influenced by seeding rates of alfalfa and/or an oat companion crop.

\section{Field experiments}

Field experiments were established in 1986 at: the high desert (Lancaster, October 9), San Joaquin Valley (Madera 1, November 20), and Sacramento Valley (Courtland, October 27). In 1987, another experiment was established at a second location in Madera (Madera 2, November 4). A split plot design, replicated four times, was used with alfalfa seeding rate $(16,24$ or 32 $\mathrm{lb} / \mathrm{ac}$ ) being the main plots and oat seeding rate $(0,8,16$ or $32 \mathrm{lb} / \mathrm{ac})$ being the subplots. Alfalfa cultivars employed varied among sites because of differences in environments. Cultivars used were 'WL 320,' 'WL 515,' '581,' and 'GT 13 R Plus' at Lancaster, Madera site 1, Courtland, and Madera site 2, respectively.

'Curt' oat, a short-statured, early maturing variety, was planted at each site. Oat was planted using a grain drill at sites established in 1986; at Madera site 2, oat was broadcast and incorporated with a disk to a 2-inch depth. At all sites, alfalfa was broadcast immediately following oat planting and was incorporated with a cultipacker. Experiments were fall seeded and flood irrigated as needed during the growing season.

Number and date of cuttings varied among locations, as did weed species (table 1). Immediately before the first cutting, forage composition and biomass

\begin{tabular}{|c|c|c|c|c|}
\hline & Courtland & Madera 1 & Madera 2 & Lancaster \\
\hline Annual bluegrass (Poa annua) & $\mathrm{x}$ & $\mathrm{X}$ & $\mathrm{x}$ & \\
\hline Chickweed (Stellaria media) & $x$ & & $\mathrm{x}$ & \\
\hline Common fiddleneck (Amsinckia intermedia) & & $\mathrm{x}$ & & \\
\hline Common groundsel (Senecio vulgaris) & & & & $\mathrm{x}$ \\
\hline London rocket (Sisymbrium irio) & & & & $x$ \\
\hline Shepherdspurse (Capsella bursa-pastoris) & & $\mathrm{x}$ & $\mathrm{x}$ & $\mathrm{x}$ \\
\hline Spiny sowthistle (Sonchus asper) & & $\mathrm{x}$ & $\mathrm{x}$ & \\
\hline Volunteer barley (Hordeum vulgare) & $\mathrm{X}$ & & & $\mathrm{x}$ \\
\hline
\end{tabular}

